九病虫研会報 $33: 210-213(1987)$

Proc. Assoc. Pl. Prot. Kyushu $33: 210-213$ (1987)

\title{
佐賀県に打けるカキクダアザミウマの発生と被害実態
}

\author{
山津 㶳治 ·村岡 実" - 御厨 秀樹 · 松崎正文 · 鶴 範三 \\ (仵賀県植物病害虫防除所・ ${ }^{1}$ 经賀県果街試験場)
}

\begin{abstract}
Occurrence of Ponticulothrips diospyrosi HAGA et OKAJIMA and crop damage by the thirps in Saga Prefecture. Kenji Yamatsu, Minoru MuRaoka ${ }^{1}$, Hideki Mikuriya, Masafumi Matsuzaki and Hanzou Tsuru (Saga Plant Protection Office, Saga 840-01. 'Saga Fruit Tree Experiment Station, Ogicho, Saga 845)
\end{abstract}

カキクダアザミウマは1975年に岡山県山陽町において 本邦での初発生が確認され（逸見，1979; 魅見・橋本， 1984）－以来分布拡大を続け，1984年には福岡県でも発生 を見るに至った（小田，1986；小松，1986；青木·大熊， 1986)。任賀県に掞いては，1985年6月 5 日に基山町小 松の力キ園 $(140 a)$ で初めて確認された。䎌1986年に は，11市町村で発生を確認したのでその分布抎大の経過 や被害状況の概要を報告する。報告に先立ち，調査に際 し多大な協力と資料の提供をいただいた岡山県農業試騟 場逸見尚氏，奈良県農業試験場小田道究氏，福岡県筑㣪 防除所深町敏生氏，佐賀県農業改良普及員抒よび営農技 術員各位に厚く御礼申し上げる。

\section{調查 方 法}

（1）カキクダアザミウマの分布拡大における年間移動

\section{距離の推定}

岡山県山陽町からその後発生が確認された各県の発生 場所までの直線距離を経過した年数で割り年間移動距離 とした。

\section{（2）佐賀県における分布と被害樹率}

1986年 $5 \sim 6$ 月に県内の栽培力キ園掞よび散在樹につ きカキクダアザミウマによる被害巻葉を調查し、市町村

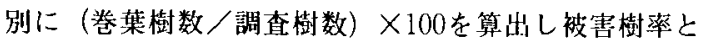
した。

（3）被害葉 1 枚当りのステージ別個体数

基山喖小松の 1 力キ園に打いて1986年 5 月22日以降 7 月19日まで 1 週間ごとに被害葉10枚を採取し，実体顕微 鏡下で卵，幼虫，成虫打よび死亡虫別に個体数を調查し た。

\section{（4）粘着トラップによる1 日当り捕獲数}

前述のカキ園に扣いて高さ $1.5 \mathrm{~m}$ に設置した黄色の木 製調查板の南北両面にタングルフットを塗った和紙（10 $\times 13 \mathrm{~cm})$ を張り 4 月から 7 月に 1 週間ごとに交換, 実体
顕微鏡下で付着した成虫数を調查し，1日当り捕獲数を 算出した。

（5）防風林からの距離とカキクダアザミウマの発生の 関係

防風林（スギ，ヒノキ）からカキ樹までの直線距離を 測定し, 各樹100葉中の卷葉数で被害葉率を，果実につ いては全結奏果実を下記の被害程度別基準で調查し，被 害果率抢よび果実被害度を算出した。

$\begin{array}{cc}\text { 被害度 } & \text { 食嗐跡数 /果実 } \\ \text { 無 }(0) & 0 \\ \text { 少 (1) } & 1 \sim 5 \\ \text { 中 (3) } & 6 \sim 50 \\ \text { 多 (5) } & 51 \text { 以_t. }\end{array}$

$$
\text { 果実被慧度 }=\frac{\text { 少 } \times 1+\text { 中 } \times 3+\text { 多 } \times 5}{\text { 調查果数 } \times 5} \times 100
$$

\section{結果および考察}

\section{（1）分布拡大における年間移動距離の推定}

カキクダアザミウマの分布拡大における年間移動距離 は, 1980年発生の莙島県, 香川県の $12 \mathrm{~km}$, 鳥取県, 兵庫 県の $14 \mathrm{~km}$ で 4 県平均 $13 \mathrm{~km}$ （逸見・橋本，1984），1982年 発生の奈良県の $27 \mathrm{~km}$ ，徳島県の $14 \mathrm{~km}$ ，愛媛県の $20 \mathrm{~km}$ 媔の平均 $20 \mathrm{kml}$ （逸見・橋本，1984），1983年発生の和歌 山県の $19 \mathrm{~km}$, 大阪府, 島根県の $18 \mathrm{~km}$ で 3 県の平均 $18 \mathrm{~km}$ （冕見・橋本，1984），1984年発生の岐阜県の29km, 滋 賀県の $23 \mathrm{~km}$, 京都府の $18 \mathrm{~km}$, 福岡県の $38 \mathrm{~km}$ (小田, 1987）で 4 府県の平均 $27 \mathrm{~km}$ であった。传賀県で初めて発 生した1985年では愛知県の30km, 三重県の $22 \mathrm{~km}$ (小田, 1987），佐賀県（基山町）の $35 \mathrm{~km}$ で 3 県の平均 $29 \mathrm{~km}$ であ り、1986年発生の山口県の $23 \mathrm{~km}$, 高知県の $13 \mathrm{~km}$ (小田, 1987)，佐賀県 (七山村) の $40 \mathrm{~km}$ で 3 県平均 $25 \mathrm{~km}$ となっ た。すなわち，岡山県に発見されてから近県 4 県に発生 
するまでの5 年間の年間移動距離は $13 \mathrm{~km}$ と短くゆるやか な分布の抎大であったが，7年目以降は18～29kmと払大 速度が速くなっており, 場所によつては40kmの移動が確 認された。

一方，イネミズソウムシ（日本植物防疫協会，1987） は1976年に愛知県常滑市において初発見されたが, その 後の分布应大をカキクダアザミウマと同様に算出した絬 果，1978年に招ける三重県等 3 祡への平均移動距離は $25 \mathrm{~km}, 1979$ 年には滋賀県の $17 \mathrm{~km}, 1980$ 年には福井県等 5 県平均で $23 \mathrm{~km}, 1981$ 年には兵庫県等 2 県平均で $28 \mathrm{~km}$, 1982年には茨城県等16県平均で46km，1983年には鳥取県 等10県平均で $59 \mathrm{hm} ， 1984$ 年には大分県等 7 罚平均で $55 \mathrm{~km}$, 1985年には沖䋲県の $140 \mathrm{~km}$ となた。すなわち，1978〜 1981年までの分布拉大距離は年平均17〜28k $\mathrm{km}$ でり, 気 流や交通機関によって应大したと考えられている11。

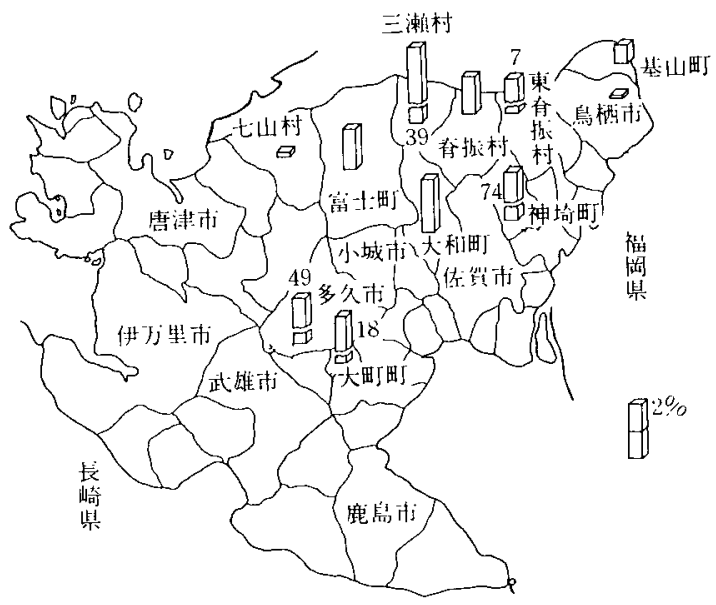

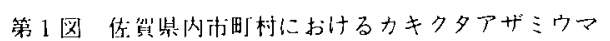
による被青樹率( 1986$)$.

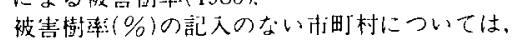
图中右横のスチールに対する枇刘比としてカ ラムで表わしておる。
1982年以降分布应大距離は46一 $59 \mathrm{~km}$ と大きくなったが, この理由には密度が高くなったことと台風により急激な 分布应大がおきたことが考えられている。(日本植物防 疫協会，1987）。以上のように, 分布应大速度は, 力キ クダアザミウマに比ベてイネミズゾウムシが速かった。 しかし，初発見から5年目までの分布搪大速度に比べて 6 年目以降の拡大速度が速くなっていることは而種に共 通していた。

小田（1987）は，カキクダアザミウマの分布拡大が気 流に乗って飛翔することによるとしているが，1984年に 抢ける本種の分仍の应大の範囲が前年に比べて著しく広 く，しかも，吅県で発見されていないのに，福岡県で 確認されたこと等を考慮すれば，父通機関等が関与して いる可能性もあり，今後唡討する必要があるように思わ れる。

\section{（2）佐賀県における県内分布と被害樹率}

1986和 5ー6月に散在樹を中心に巻葉被害を調查し, それにもとづき県内分布を市町村別の被害樹率として第 1 図に示した。分布は1985年の1町から，1986年には11 术町村に摭大した。被害樹率で最も高かったのは神埼町 の74\%，次いで多人市 $49 \%$ ，三瀨村 $39 \%$ で，県平均 4.1\%であった。1986年の発生地の中で基临町から最も 裳い七山村までの分们拡大距離は $40 \mathrm{~km}$ であり，この速度 で今㣪も掋大すると1987年には県内全域に应大する可能 性がある。

\section{（3）被害葉 1 枚当りステージ別個体数}

5 月22日以降 1 週間ごと採取した被害葉について， 幼出，成虫括よび死亡虫数を第 1 表に示した。被害葉 1 双当り個体数は 5 月22日の41頭加 6 月14日の388頭ま で増加し、その後减少した。6月14日以降の倜体数の減 少は新成虫が葉から脱出したためと思われた。

新成出の産下即あるいは次世代幼虫が，6月中旬以降 (逸胃·橋本，1983），7月上旬（賀川，1984），7月中

第1表 カキクダアザミウマの被害葉】枚当りのステージ別個体数の推移（佐賀県基山町; 1986）

\begin{tabular}{|c|c|c|c|c|c|c|c|c|c|c|}
\hline \multirow{2}{*}{ 採取月日 } & & 第 & 世 & 代 & & & 第 & 世 & 代 ${ }^{1)}$ & \\
\hline & 畉 & 纤虫 & 成虫 & 死亡虫 & 部 & 哪 & 幼虫 & 成虫 & 死亡中 & 部 \\
\hline 5 月22日 & 36.7 & 4.1 & 04 & 0 & 41.2 & - & - & - & - & - \\
\hline $31 \mathrm{~B}$ & 56.0 & 55.8 & 0.8 & 0.1 & 112.7 & - & - & - & - & - \\
\hline 6月 7 日 & 31.5 & 273.4 & 8.7 & 0 & 313.6 & - & -- & - & - & - \\
\hline $14 \mathrm{~B}$ & 0 & 148.1 & 239.5 & 0 & 387.6 & - & - & - & - & - \\
\hline 21日 & 0 & $8: 3.6$ & 215.9 & 0 & 299.5 & 8.8 & 21.6 & 38.8 & 0 & 69.? \\
\hline 28日 & 0 & 21.7 & 20.8 & 0 & 42.5 & 0 & 60.0 & 3.7 & 0 & 63.7 \\
\hline 7月 5 日 & 0 & 1.7 & 1.3 & 7.4 & 10.4 & 0.8 & 8.6 & 6.6 & 0 & 16.0 \\
\hline $12 \mathrm{~B}$ & 0 & 0.2 & 2.9 & $4.8^{\prime}$ & 7.9 & 0 & 0.1 & 1.9 & 4.0 & 6.0 \\
\hline 19日 & 0 & 0 & 0.3 & 7.6 & 7.9 & 0 & 0.2 & $\cdot 1.0$ & 5.6 & 6.8 \\
\hline
\end{tabular}

1）一は，第2 世代が確認さ机なかった。 
旬（松本ら，1985；小田，1986），8月上旬（松本ら， 1985；小田，1986），8月（山田，1987）と各地の徒長 枝上で観察され，本害虫個体群の一部は第 2 世代を経過 することが示唆されている。本県においても 6 月21日に 徒長枝上の生長の遅れている苯に新しい被害が見られて いるが，これは第 2 世代の加害によるものと思われた。 その理由として，6月14日には被害葉中に卯が既に無い こと、5月22日に第 1 世代成虫が現れて既に約 1 か月を 経過していること，新しい被害は徒長枝で遅くまで伸長 し続けている葉にのみみられることなどが挙げられる。 越冬成虫による被害葉率 $8.0 \%$ に対し，新成虫による被 害葉率は $0.1 \%$ 以下で著しく少なかった。また，被害葉 1 枚当りの最大個体数は，第 1 世代の 388 頭に比べて,

第 2 世代は69頭と $1 / 7$ に低下した。なお，第 1 表に示 したように，第 1 世代の各発育段階別個体数を見ると， 産卵開始時期を確認出来なかったものの，被害葉 1 枚当 りの卵，幼虫抢よび成虫の個体数が，それぞれ 5 月31日， 6 月 7 日，6月14日をピークに推移した。

第 1 世代成虫の死亡は力キ樹上生活終期の 7 月 5 日以 降に認められたが，総個体数の最高が388頭と多かった にしては死亡虫は 5 ～8頭と少なかった。第 1 世代成虫 によると思われる食害は 6 月14日に認められたが，6月 21日には第 2 世代の卵，幼虫扣よび成虫が観察された。

7 月19日にはほとんどが第 2 世代成虫になり葉より離脱 した。第 2 世代成虫の死亡個体は総個体数の最大が69頭 と少なかったにもかかわらず 4 〜頭と第 1 世代に比べ

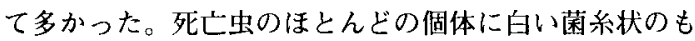
のが付着していた。小田 $(1986 ， 1987)$ は死亡個体は Beauveria bassiana 菌に侵されていることを認めており， 前述の死亡の原因も同じものと思われる。

(4) 粘着トラップによる捕獲

第 2 図は，1986年基山町カキ園での粘着トラップによ る捕獲数と被害葉中の成虫数 (第 1 表) の変化を比較し たものである。トラップは園の 4 個所にそれぞれ南向と 北向に各 1 枚ずつを設置したが，方位による捕獲数の差 は認められなかった。力キ園の端の越冬場所（スギ林） の近くに設置したNo.1 トラップで最も多く捕獲され， 被害葉率の高い所の No. 2, 低い所の No. 3 拉よびカキ 園に隣接した雑木林中の No.4トラップでの捕獲数は少 なかった。いずれのトラップでも捕獲時期が 6 月 4 日か ら7月23日までであったことから捕獲された成虫は越冬 成虫ではなくす心゙て第 1 世代打よび第 2 世代成虫であっ たとみなされる。No.1トラップで捕獲数が多かったの は，第 1 世代および第 2 世代が力キ園から越冬場所（ス ギ林）八移動するためであろうと思和れる。No.1 打よ
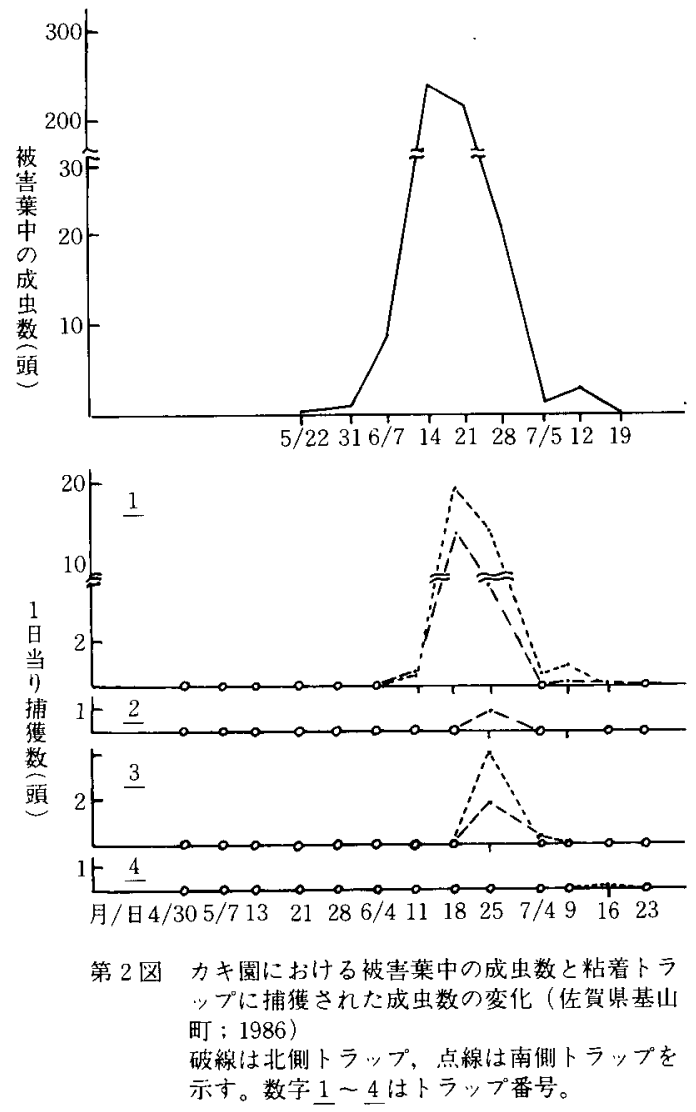

びNo. 4 トラップでは 7 月23日まで捕獲されたのに対し， No. 2 およびNo. 3 トラップではそれぞれ7月 4 日およ び7日までしか捕獲されなかった。このことは, No.1 とNo.4トラップを設置した越冬場所（スギ林）近くで は本虫が比較的遅い時期まで飛翔していることを毫づけ ていると思われる。ステージ別個体数の推移とトラップ による捕獲成虫数の変化からみる限り，本虫による果実 加害は 6 月に集中し，7月にはほとんど加害されないと 思われた。

（5）防風林からの距離とカキクダアザミウマの発生の 関係

逸見ら（1981）は本種の発生源として，カキ園および アカマツ林がかなりの比重を占めているとし，アカマッ 林に近い力キ樹での寄生数が多い傾向を認めている（逸 見. 1979. 逸見・橋本，1984）。賀川（1984）はクヌギで, 小松（1986）はカキおよびスギで，小田（1986，1987)

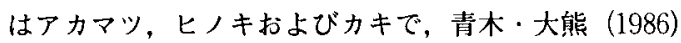
はカキでいず机も樹皮下で越冬することを認めている。 本県での越冬はスギ，ヒノキ，マッ拉よびカキで認めら れた。第 2 表は, 県内 2 力所の被害の見られた力キ園に 
第2表 2つのカキ園におけるカキクダアザミウマの発生と防風林からの距離の関係（佐賀県; 1986)

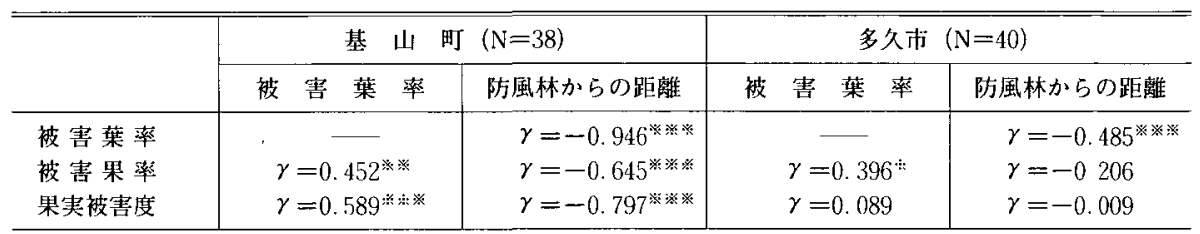

(注) 危険率 $※ 5 \%, ※ ※ 1 \%, ※ ※ ※ 0.1 \%$ で有意

おける防風林（越冬場所）からの距離と被害葉率および 被害果率, 果実被害度との関係について検討したもので ある。多久扐力キ園における被害葉率は0.3\%で，基山 町カキ園の $8.0 \% に$ に比べ低かった。いずれかのカキ園で も防風林からの距離と被害葉率との間に負の相関が涩め られた。基山町力キ園においては防風林からの距離が 10 $\mathrm{m}$ 程度までのカキ樹で著しく高い被害葉率が認められ， $25 \mathrm{~m}$ を越すと低くなった。しかし，多久市力キ園におい て被嗐葉率が高かったのは $5 \mathrm{~m}$ までの樹であった。この ように，防風林から高い被害葉率がみられる樹までの距 離に, 差があるのは両園内の本種の密度の違いによるも のと思われる。

小田（1986，1987）は, 越冬場所に近いほ場で被害果 率および果実被害程度が高くなるとしている。著者らの 調查でも防風林からの距離と被害果率抢よび果奏被害度 との間には負の相関が認められ，基山町力キ園では防風 林か $520 \mathrm{~m}$ 以内で被害果率が高く, 果奏被害度は $15 \mathrm{~m}$ 以 内で高くなった。

基乡叮力キ園では被害葉率と被㕩果率との間に $\gamma=$ 0.452 , 被害葉率と果実被害度の間には $\gamma=0.589$ と相関 係数はあまり高くないが正の相関が認められた。晩見・ 橋本 $(1983 ， 1984)$ は被害葉率が高いほど果実被害度が 高くなるが，被害葉率が低くても被害果斝が高くなる場 合もあり，成虫が個々の被害葉からかなり広範囲の果夷 に分散加害するとしている（逸見ら，1981; 藤木·高垣， 1985)。本調查においても相関係数があまり高くなかっ たのはこのような理由によるものであろう。

\section{摘}

要

カキクダアザミウマの分布拡大速度は 1 年に 20 ～ $30 \mathrm{~km}$ で，佐賀県内では最高40km 記録した。佐賀県では1985 年に初発生し，翌年には11市町村に抎大し平均被害樹率 は4.1\%に達した。越冬成虫から生じた被害葉 1 枚当り の最大個体数は388頭, 第 1 世代成虫からでは69頭であ った。本種の発生をステージ別に見ると, 卵数のピーク は5月31日，幼虫のピークは 6 月 7 日，第 1 世代成虫の ピークは 6 月14日であった。粘着トラップ捕獲数は越冬 場所近くの力キ園周辺部で多かった。越冬場所に近いほ ど被害葉率, 被害果率および果夷被害度が高かった。

\section{引用 文 献}

1）青木 敏 - 大熊正寛（1986）落葉果樹試験研究成續概要集 一虫害一農林水鏟省果樹試験場編一：93-94. 2) 藤木大 生・高垣 治（1985）福山地域におけるカキクダアザミウマの 発生上防除廣島県福山病害虫防除所：1-29，3）逸罗 尚 （1979）植物防疫 33:231-235. 4) 逸兒 尚 - 永井一哉・清 家邦彦（1981）落葉果樹に関する試験研究打合せ会議病虫害部 会資料一虫害一 農林水産省果樹試験場編：152-156. 5）逸 兒 尚・橋本修二（1983）落葉果樹の病虫害に関する重要研究 問題検討会虫害分科会資料 農林水産省果樹試駼場編：255-257, 271-273. 6) 逸罗 尚. 橋本修二（1984）植物防疫 38 : 312-315．7）賀川実（1984）落葉果樹の病虫害に関する特 定課題研究会虫害関係資料農林水産省果樹試験場編： 267-272. 8) 小松秀男 (1986) 落葉果樹試験研究成績概要集 一虫害一農林水産省果樹試験場編：73-75. 9) 松本 要. 田中敏幸·川上浩幸·藤林大生・高垣 治（1986）落葉果樹試 験研究成績概要集一虫害一莀林水産省果樹試験場編：77-78. 10）日本植物防度協会（1987）イネミズゾウムシの防除一被害 ゼロをめざしてー：1-30. 11）小田道宏（1986）落葉果樹試 験研究成䋶概要集一出害一農林水産省果樹試験場編: $57-58$, 61-66. 12）小田道宏（1987）カキクダアザミウマの生態と防 除対策枱討資料 奈良県農林部：1-15. 13) 山田健一 （1987）落葉果樹試験研究成績概要集一虫害一農林水産省果 樹試験場編：79-84.

(1987年5月 7 日 受領) 